\title{
Epidemic keratoconjunctivitis outbreak in a closed psychiatry ward
}

\author{
P Rodriguez-Perez ${ }^{*}$, NV Vendula, C-C Mireia, ZA Ana \\ From International Conference on Prevention \& Infection Control (ICPIC 2011) \\ Geneva, Switzerland. 29 June - 2 July 2011
}

\section{Introduction}

Epidemic keratoconjunctivitis (EKC) caused by adenovirus is a highly contagious infection of the eye frequently associated with healthcare services.

\section{Objective}

Description and analysis of an outbreak of epidemic keratoconjunctivitis (EKC) in a psychiatry ward of Gregorio Marañón General University Hospital, Madrid, Spain, which occurred during the months of May and June 2010.

\section{Patients and methods}

The outbreak occurred on a closed unit of the Psychiatry Department with 26 beds in 22 rooms. At the moment of the alert, 22 beds were occupied. The management of the outbreak consisted of reinforcement of hygiene measures and workshops on hand hygiene for the ward staff. The emergence of new cases in patients as well as in staff members lead to the restriction of new admissions and eventually to the closure of the unit.

\section{Results}

Altogether, 13 cases of EKC were identified among patients (12 probable cases and 1 confirmed case). There were 2 probable cases identified among staff. The overall attack rate was $22.4 \%(13 / 58)$ among the patients and $11.7 \%(2 / 17)$ among staff.

\section{Conclusions}

As far as we know, this is the first description of an EKC outbreak in a psychiatry ward where nosocomial infections are rather rare. The psychiatric pathologies of

Medicina Preventiva, Hospital General Universitario Gregorio Marañon, Madrid, Spain the patients of this specific unit caused many difficulties in the reinforcement of strict preventive measures and in the therapeutic management of these patients.

\section{Disclosure of interest}

None declared.

Published: 29 June 2011

doi:10.1186/1753-6561-5-S6-P97

Cite this article as: Rodriguez-Perez et al:: Epidemic keratoconjunctivitis outbreak in a closed psychiatry ward. BMC Proceedings 2011 5(Suppl 6): P97.
Submit your next manuscript to BioMed Central and take full advantage of:

- Convenient online submission

- Thorough peer review

- No space constraints or color figure charges

- Immediate publication on acceptance

- Inclusion in PubMed, CAS, Scopus and Google Scholar

- Research which is freely available for redistribution

Submit your manuscript at www.biomedcentral.com/submit

\section{() Biomed Central}

\section{Biomed Central}

